\title{
C) HISTT́ÓRICA
}

\section{Conflicts among religious people in a Catholic mission in the countryside of Goiás state in the I950s: Resentment of Remigio Corazza in his autobiographical account}

\author{
Raylinn Barros da Silva*
}

\begin{abstract}
The aim of this study was to uncover the conflicts that occurred between religious people inside of the Orion Catholic mission in the old extreme north of Goias state in the middle of the 2oth century. One hypothesis is the possibility that these conflicts may have influenced at some point in the development of the mission. This study is the result of a bibliographical research and the source used was the memory report - autobiographical book Silence Prudent - of one of those religious members: Remígio Corazza. The methodology was based on an analysis of the work having as reference studies on autobiographies, memory and resentments. A justification for this study is the need to historicize this source that can contribute to the understanding of the Orion mission in the region by another bias: the internal conflicts among some of its members.
\end{abstract}

Keywords: Goiás; Orionites; Conflicts, conflicts.

\section{Introduction}

This study aimed to unveil the conflicts that took place between some religious in the context of the Orionite Catholic mission in the region of the ancient northern tip of Goiás, a region where northern Tocantinense is currently, in the middle of the twentieth century. From the autobiographical accounts of the missionary Remígio Corazza and, above all, his resentments towards another Orionite, Giovani Pattarello, it is hypothesized that these internal conflicts during the mission may have influenced at some point the unfolding of the same in the temporal and spatial context addressed.

The main justification for this investigation was the need to historicize these reports of Corazza, which is believed to contribute to the understanding of the Orionite mission in

\footnotetext{
* PhD student and Master in History from the Graduate Program of the Federal University of Goiás. Specialist and Degree in History from the Federal University of Tocantins. Author of the book: Pedro Milagroso, the beggar turned saint, Editora Kelps, 2013.
} 


\section{C) HististóricA}

the region, but on another bias: that of some internal conflicts among its members. But which sources were used in this study? What challenges have been posed to carrying out this research? The materials used in this study are objects of observation to follow.

\section{The documentation and challenges of its use}

The documentation used in this study consisted of the autobiographical accounts of Remígio Corazza, an Orionite missionary who participated in the mission in Goiás since the first year. Corazza wrote two works of memory, one in particular related to the objectives of this study, the book Silence Prudente. Published in the early 20oos, in it, Corazza apparently decided to report in a type of writing loaded with resentment, some moments with wealth of details, behind the scenes of the mission in Goiás, especially, according to him, the "maneuvers" triggered by whom he points out as responsible for persecutions and internal disputes in the mission, also Orionite priest Giovanni Pattarello.

Peter Gay, a German historian, scholar of the so-called psycho-history, reflecting on the relationship between resentment and suffering, infers that these feelings when submitted to the space of religion, becomes an explosive theme, because, most of the time, those who retain certain experiences in memory report them as extraordinary events and, in most times, as traumatic experiences or even resentments (GAY, 1999, pp. 337-376). Apparently, Corazza's memoir had this aspect: an explosive place that brought about his resentments, sufferings, his traumatic experiences as a result of his troubled relationship with Pattarello.

As for these autobiographical memory records of Corazza, it should be inferred that some limitations were imposed in the investigation and consequent performance of this study. The first challenge, which imposed an immediate limitation, is the absence of precise references on the dates on which each conflict occurred, each persecution, according to Corazza, by Pattarello. Therefore, Corazza brings in his autobiographical accounts riches of details, but does not inform the exact moment at which they gave themselves. For this reason, it was not possible to organize this study divided into historical periods, the only precise reference is that they occurred in the I950s and beginning of the following decade, that is, in the first ten years of the Orionite mission in Goiás.

Because they are accounts of memory, the voice of one religious: Corazza, imposed a unique version for the narrative and the consequent analysis. But from the beginning, when we noticed the absence of other versions for Corazza's memory records, such as 


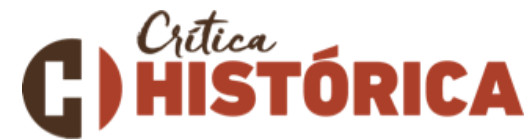

Pattarello's version or even the Orionite congregation, he made us work exclusively with Corazza's accounts and that, by this reason, increased the challenge of historicizing a "oneway" document, but which is believed not to diminish the analytical capacity of this investigation.

But which congregation do these missionaries belong to? Who is the founder of this religious group? How did this congregation spread throughout the world? What were the first Orionite missionaries assigned to Goiás at the time? How did they find the area? What country-level church project does the Orionite mission in Goiás fit into? These are the issues that guide the reflection to follow.

\section{The Orionite missionaries: who are they?}

Orionite missionaries belong to the congregation called the "Little Work of Divine Providence". They are called "Sons of Divine Providence" or simply "Orionites". This religious congregation belongs to the Catholic Church, founded by the Italian priest Don Luís Orione. The Orionite missionaries are Catholic priests and religious who in the 2oth century dispersed throughout the world, more precisely from the post-first war, imbued with an ideas of life and $\mathrm{d}^{\mathrm{I}}$ service to the Catholic Church and of assistance to the poor, these precepts were the guiding of the life of Don Luís Orione (PATTARELLO, I985, p. 9).

About this Catholic religious congregation, it is considered one of the newest in the structure of the Catholic Church. Very few academic works address this congregation, it is known that it has as its field of activity the assistance to the poor and, above all, the practice of charity, through the provision of education, health and culture, besides, of course, religious assistance in their temples - churches - around the world. The so-called Orionite charism is based on this premise: charity. Specifically, about the presence of this Orionite congregation in the space of the ancient north of Goiás, the geographer Jean Carlos Rodrigues notes that:

\footnotetext{
${ }^{\mathrm{I}}$ Don Luís Orione, in Italian Luigi Orione was born in Pontecurone, Italy, in I872 and died in Sanremo in I940. Upon entering religious life, he belonged to the congregation of salesian priests, a religious order founded by the priest Don Bosco, from whom Don Orione enjoyed friendship. Don Orione lived his life practicing charity. In 1903 he founded in the city of Tortona the Small Work of Divine Providence, composed of priests, nuns and consecrated laity. Present almost all over the world, it is maintained with donations from Catholics. From the middle of the 2oth century his followers spread throughout the world, including Brazil. Their religious are called "Sons of Divine Providence". He was beatified in 1980 and canonized in 2004, the two ceremonies presided over by then Pope John Paul II. For more information on the life and work of Don Orione, see: PATTARELLO, Giovani (2009). Dom Orione's Profile. São Paulo: S/Editora, 1985.
} 


\section{C) CitsistórICA}

The arrival, installation and dissemination of the Congregation of the Small Work of "Divine Providence" in the north of the State of Goiás in the I950s was able both to print religious forms in the landscape (construction of churches, schools and hospitals) and was also important for to constitute a Christian religious identity, of Roman Catholic aspect, of Orionite charism in this region (RODRIGUES, 20I6. p. 52).

As Rodrigues reflected, the presence of the Orionite congregation changed the landscape of the region through its constructions - churches, schools and hospitals - and that, according to him, this presence contributed to the constitution, from the Orionites, to a Christian identity of orionite charism, that is, the charism of the congregation for it is linked to these spheres: church, education and health, dimensions in which the congregation, in our view, acts in the sphere of charity.

This congregation and its members, the orionites, are present in almost all continents, with a more outstanding performance in Latin America and Europe. About the missionaries who were assigned to the region of the ancient northern tip of Goiás, presentday north tocantinense, in February 1952, there were not many, but those who went to the region have transformed into the protagonists of the process of institutionalization of the Catholic Church that took place in the context ${ }^{2}$.

They settled in the Territory of Goiás in the early I950s and even to this day are in it. With the division of Goiás in 1988 giving rise to Tocantins, the Orionite missionaries have expanded their mission, today they have day care centers, elementary and high schools, a college, reception houses, social care centers of elderly people, hundreds of churches and A hospital, considered the largest and most modern in northern Tocantinense. Orionites are no longer considered to be on mission through the region as they were in the I950s and I960s. Although they still consider themselves missionaries, it is believed that the work of the congregation in the region is consolidated, due to the scope of their work in the region.

The first Orionite missionaries who were assigned to the region were: Quinto Tonini, Pacífico Mecozzi, Teresinha Foli and Remígio Corazza. Giovanni Pattarello did not serve in the region as a missionary, but his behind-the-scenes participation in the mission transformed him, according to Corazza, into a central character of the conflicts that occurred within the mission.

\footnotetext{
${ }^{2}$ The process of institutionalization of the Catholic Church in the region is not a topic of reflection in this study. For more information on the subject, see: SILVA, Raylinn Barros da. Orionite Catholicism in the Ancient Northern Goiano In the Accounts of Memory of the "Sons of Divine Providence" 1952-I980. Master's thesis. Graduate Program in History. Goiânia: UFG, 2017.
} 


\section{C) Hitceatórica}

On Tonini, in the early years of the Orionite mission in the region, from 1952, he acted as an almost undisputed leader within the mission. Upon arriving in the region with his nursing knowledge, he acted as a kind of priest-doctor, treating and healing the sick. Where he was displaced, he built churches, opened schools and health posts. Soon after his arrival in the region, he was recognized for his work and skill, which assured him the status of leader among the Orionites in the region. ${ }^{3}$

On Mecozzi, he was considered one of the main missionaries aligned with Tonini, after the resignation of the latter, he was designated as vicar capitulant of the prelature of Tocantinópolis from I959 to I960. It is believed that Mecozzi would not have stayed longer in office because the superiors of the Church in Rome would soon seek a solution to the problems of the church in the region, or even, the appointment of a Bishop would put an end to internal disputes for power within the church in the Region. ${ }^{4}$

About Teresinha Foli, she was a orionite nun, was the only one of Tonini's allied group who was not foreign, was from the mission region, the small town of Philadelphia, one of the main centers of action of the missionaries. It also did not belong to the first group of those who worked in the region. Tonini, upon arriving in Philadelphia in 1952, stayed at her parents' house at the time very young, soon entered the seminary and chose to belong to the Congregation of the Little Missionary Sisters of Charity, the feminine arm of the Orionite congregation (FOLI, 2003, p.19). ${ }^{5}$

About Corazza, in the group very close to Tonini, was Pattarello's harshest critic. During this study, he was the only one of the missionaries still alive. Like Pattarello, he also met and lived with Don Orione. He was ordained a Catholic priest in 1952, twelve years after don Orione's death, and in the same year he joined the Orionite mission in the region. The

\footnotetext{
3 Tonini was the first apostolic administrator of the Tocantinópolis prelature from 1956 until his resignation in 1959. Like Corazza, Tonini left his autobiographical work, the book Between Diamonds and Crystals, produced by Editora Expressão, Fortaleza, 1996. This autobiographical work of Tonini has no preface and according to the author was not even authorized by the congregation much less received from the same congregation financial support to be published.

4 Mecozzi belonged to Tonini's group, the fact that he replaced him demonstrates, it seems, the influence that Tonini still had in the region. Mecozzi, in this plot, occupies the place of Tonini's ally, in corazza's memory narratives, he considers Mecozzi as Tonini's trusted man and ally of the same at the time. Mecozzi, from the group of the first missionaries who worked in the region, was the only one who left no autobiographical book produced.

${ }^{5}$ It is interesting to note that the memory records of both Tonini and Foli lead us to believe that they fed until the final days of their lives a passion that, believed, may have interfered in the course of the mission. Foli, like Tonini and Corazza, also left his autobiographical book, the work Insands of Truth, produced by Editora GM, 2003. Foli's autobiographical work, as well as that of Tonini and Corazza, has no preface and according to the author was not even authorized by the congregation much less received from the same congregation financial support to be published.
} 


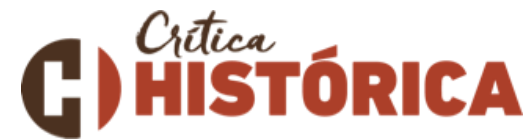

following year, 1953, he was sent to Tocantinópolis as a missionary. ${ }^{6}$ On Pattarello, during the Orionite mission in Goiás, he was the superior general of the missionaries in Brazil, the largest position of the congregation in the country. ${ }^{7}$

Establishing a relationship between the Orionites and the history of the region in which they operated, how was northern Goiás before the Orionites arrived in the region? From the point of view of the Catholic religion, the ancient northern tip of Goiás - with the exception of Boa Vista, present-day Tocantinópolis, already had a Catholic parish - was "assisted" from a religious point of view, time and time again, when passing religious missions. First the Capuchins at the end of the I9th century and, at the beginning of the 2oth century, the Dominicans.

About the latter, the historian Vera Caixeta informs that in the first decades of the twentieth century "The friars are still responsible for the Diocese of Porto Nacional and the Prelature of Conceição do Araguaia. Thus, the friars were already fully structured in Central Brazil, with an experience of more than twenty years in the interior of Brazil" (CAIXETA, 20I4, p. 89). The first records of the Church's actions in the region were due to these religious, but an action as a mission, not as an institutionalized church. The Church Catholic was not structured as a temple built and with customary celebrations. That is, before the Orionite missionaries, the region from time to time received the visit of Catholic missions passing through the place.

\footnotetext{
${ }^{6}$ From Corazza's memory accounts, it is possible to realize that during the mission, he became besides Tonini's friend, his "right-hand man". Your autobiographical book Prudent Silence, was produced by Editora Expressão, 2000. This work is the only one that approaches the Orionite mission behind its internal backstage, he presents in this book his autobiographical, which can be understood as the other side of the Orionite mission in Goiás at the time. This autobiographical work of Corazza, as well as that of Tonini and Foli, has no preface and according to the author was not even authorized by the congregation much less received from the same congregation financial support to be published.

${ }^{7}$ Pattarello, as well as Tonini, Foli and Corazza, also left his writing, the biographical book in which he talked about the biography of the founder of the Orionite congregation, the book Dom Orione's Profile, produced independently, without a publisher, in 1985. Unlike the autobiographical works of Tonini, Corazza and Foli, corazza's book received financial support from the congregation to be published.
} 


\section{C) Hitstótórica}

Image I: Map of the Orionite mission in the first two decades of operation in the region, covered by cities.

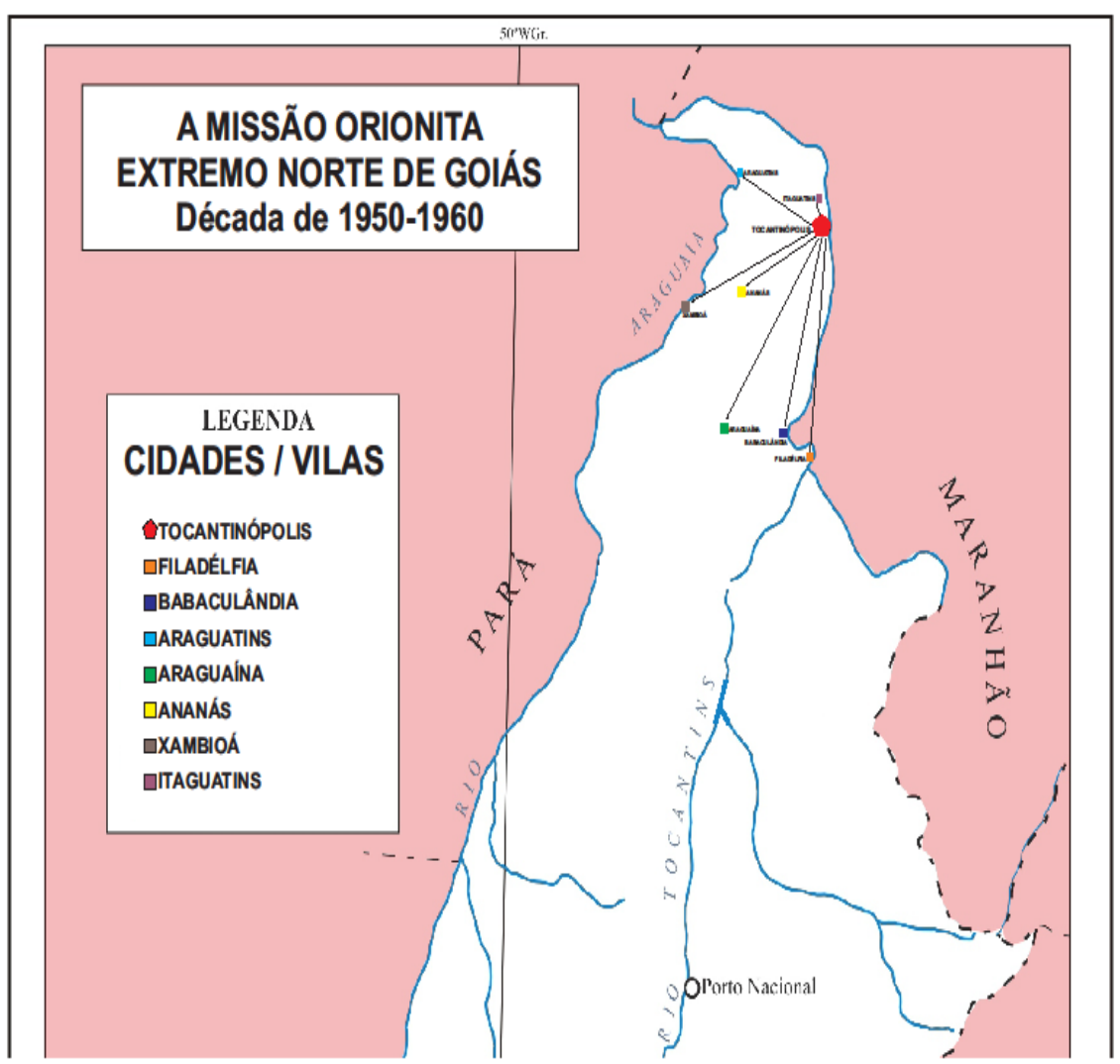

Source: Image produced from the reading of the autobiographical sources of orionites

Already establishing a relationship between the Orionites and the history of Brazil in the period, especially the history of the Catholic Church at the national level in the context addressed in this study, it can be inferred that the performance of the Orionite missionaries in Goiás was inserted in the context of the so-called neocristandade. In this sense, which project at the Level of Brazil was being put into practice by the Catholic institution? To reflect on this problem, it is worth noting the note outlined by historian Riolando Azzi, one of the most prominent specialists in the study of Catholicism in the country. According to him, the Catholic project sought:

Valuing the role of religion in the maintenance and cohesion of the social order. Brazilian prelates go even further in their claims: they wish that, in fact, the Catholic faith can be the inspiring principle of action government leaders and the society's own legal and social organization. They want Brazil to effectively become a Christian State, that is, a new Christianity (AZZI, 1994, p. 60). 


\section{G) Hiticátórica}

According to Azzi, the Catholicism project for Brazil in that historical context of the early twentieth century, a project called neocristandade and which still showed strength in the I950s onwards with the Orionite missionaries in the former northern tip of Goiás. How did the joints between the Orionites get along? What conflicts occurred? Who was behind them? The Orionite mission seen from the perspective of Corazza, one of the main missionaries who worked on the mission, is the object of the following reflections.

\section{Behind the scenes of the Orionite mission in Goiás: internal conflicts seen from the resentments of Remigio Corazza}

As we know, the analysis of the backstage of the Orionite mission was based on the memory records of the missionary Corazza who, in reporting his life in the context of the Orionite mission in Goiás, ended up bequeathed notes that allow us to see the same mission by another bias: from its backstage. For dealing with these memories, the studies of Ecléa Bosi were used, in which she sought to analyze the discourses of the elderly from the reconstruction of their memories, in addition to their insertion in society. According to Ecléa Bosi,"The account of life itself is the testimony of eloquent hands of the ways one has to remember. It is his memory" (BOSI, 2003, p. 68). It is believed, therefore, that Corazza's memory records are his testimony, his memory of events.

In these events, according to Corazza, was a character who, according to him, was a persecutor and articulator of several "plots" that were part of the religious mission at the time. The "tormentor" of some Orionites was an Italian priest who in the context of this study was the provincial of the Orionite congregation in Brazil: Pattarello. According to Corazza, he pursued and plotted against Tonini and the missionaries who were under his influence, including himself, Corazza. Pattarello and his life trajectory is little known. However, through his memories, he knows that he met and lived with Don Orione. In the I950s he was appointed as superior of the Orionites in Brazil, a provincial position he held for several years (PATTARELLO, I985, p. II).

About his work of memory entitled 'Prudent Silence', it is his autobiographical record. For the deal with this source, this study was based on the Reflections of Mary Lígia Leite Pereira, when she reflects that in some autobiographical studies, the narrator is the one who gives the referral that best considers for his life history, because, according to her:

An autobiography consists of the narrative of one's own existence and, as Maria Isaura Pereira de Queiroz (1988) points out, in it was the narrator himself who was willing to narrate his life, gave her the direction that 


\section{C) CitsistórICA}

seemed best to him and held control over the means of (PEREIRA, 2000, p. II8).

On the writing, it can also be inferred that it is a memory record impregnated with resentments by Pattarello. For this reason, pierre ansart's reflections were used in this study. For him, in studies on resentment, it is necessary to observe the existence of various forms for the manifestation of it. Ansart believes that in addition to the absence of affection, other feelings such as revolt, in addition to discourses and representations may play a relevant role in the manifestation of resentment (ANSART, 2004, p. I6).

Tonini was the missionary who stood out most at the time of the mission. It is believed that, as evidence that his work was widely recognized by the Church four years after his arrival in 1956, he was appointed apostolic administrator of the Catholic Church in the region. At the time, it was believed that the post of apostolic administrator would result in his conversion into bishop. According to Corazza, from the choice of Tonini for the position, the life of the latter and Pattarello "crossed" and how it will be possible to perceive, to the "unhappiness" of Tonini. But why Tonini's unhappiness?

Because when the choice of the same as apostolic administrator for the region, his name was in internal dispute with ${ }^{8}$ more other names among the Orionites, among these stood out Pattarellohimself, it seems, pleaded for the position given to Tonini. From the choice of the Vatican by the name of Tonini for the administration of Catholics in the region, began Pattarello's rivalry against Tonini, rivalry that lasted until 1959, when Tonini resigned from office. The rivalry between the two caused difficulties for both Tonini and those closest to him, such as Corazza himself, as well as Mecozzi and Foli.

On Tonini's resignation as apostolic administrator, Foli recorded that days after she had given up, she received a visit from Tonini himself who had just left the head of the mission and was on her way to Uruguay. According to her:

After leaving Tocantinópolis I was destined to work in Siderópolis, Santa Catarina. One morning the bell rang. I went to answer and came across Fr. Mr. Tonini. I asked for friends and relatives that I had left in Goiás. I noticed he was taciturn, strange, different. When I asked him if he could take a letter from me to Dad, he replied: I'm not going back to Goiás anymore. I'm here in my way to Uruguay, my new field of work. As? Are you telling me you

\footnotetext{
${ }^{8}$ On the choice of Tonini and the fact that Pattarello was deprecated at the time by the Vatican, see: FOLI, Teresinha de Jesus Nóbrega. Insands of Truth. Fortaleza: GM Editora, 2003, p. 9.
} 


\section{G) Citsistórica}

left the mission and you're leaving Brazil, too? Yes, I did. Pe. Tonini told me the reasons that led him to that resolution. I did not notice in him any feeling of revolt, but a deep sadness, which I tried to hide (FOLI, 2003, pp. I2-I3).

As Foli recorded, Tonini visited her shortly after her resignation. She did not explain the reasons that led Tonini to resign, preferred to hide them. An attentive observation of Foli's narrative leads us to believe that it was not a spontaneous renunciation. If so, Foli would not have recorded in his memoirs the expression "I didn't notice in him any sense of revolt". If Tonini had resigned for personal reasons, that is, a decision without pressure, why would Foli make the observation that he had not perceived a sense of revolt in Tonini? She also highlighted the missionary's sadness in reporting her resignation.

Although the title of Corazza's memory work suggests that he was cautious, it is not what is observed in his narrative. There is an explanation for the title "prudent silence". It was published in 2000, shortly after Tonini's death and three years after Pattarello's death. It is as if Corazza said that the silence that had been prudent was no longer necessary. From then on, he wrote what he knew: behind the scenes of the mission of which he himself was a witness. Thus, Corazza in his memoirs, he points Pattarello as who conspired against Tonini when he recorded:

In Tocantinópolis, headquarters of the Orionite mission, the Pauline slogan "it's good to wish to be bishop" was notorious and there was no shortage of suitors, although everyone knew that there was already a summit advocate waiting. In a letter written by the provincial himself of the time, Fr. Pattarello, to a fellow friend, Fr. Peaceful, he promised a good amount of money for the construction of the church of Araguaína, clearly demanding change: "let us drop the stone on the pawn and the little king (Father Tonini) will fall alone" Emphasis Added (CORAZZA, 2000, p. 6I).

As noted, Corazza made clear what was happening in the late I950s within the Orionite mission in the region: a dispute over power that materialized in intrigue. Intrigues that were implanted by the provincial orionites in Brazil at the time, Pattarello, against the apostolic administrator of the Orionites in Goiás, Tonini. Corazza went straight on his record and bluntly exposed the backstage of the mission. 


\section{G) Hiticátórica}

First, it refers to the year 1959, when Tonini was the apostolic administrator of the Catholic Church in the region. Apostolic administrator within the hierarchy of the Church is a provisional position, usually the apostolic administrator governs until the choice of the bishop, his substitute. That is, Tonini's term as administrator was coming to an end, the process of appointing a bishop to the church in the region would be a matter of time. Tonini could be appointed bishop and confirmed in office definitively or chosen another priest among the religious to administer the Church of the region as bishop.

Years earlier, Pattarello had lost the race for the post of apostolic administrator to Tonini, and in 1959, it seems, he then began to move to remove Tonini from his position and mission in the region and "speed up" the choice of his replacement, himself, It is believed. Corazza recorded that there were suitors for the post, certainly Pattarello was the strongest candidate. Corazza recorded, therefore, that Pattarello wrote the letter to Mecozzi, an Orionite missionary in Araguaína, an important center of the mission.

In the correspondence, Corazza recorded that Pattarello asked mecozzi for mecozzi's support for the plan to "overthrow" Tonini from the position of administrator so that his succession was opened and, consequently, the appointment of a bishop, it seems, he himself wished to be so and, surprisingly, it conditions Mecozzi's request for support to the sending by him, Pattarello, of financial resources for the construction of the church in Araguaína. That is, Pattarello tried, according to Corazza, to bribe Mecozzi in exchange for support for his plan against Tonini, which he called "little king." With this term, Pattarello's intention was to inferiorize and ridicule Tonini.

In his autobiographical narrative, Corazza brings the backstage around the Orionite congregation with clarity. It presents the intrigues as a kind of history parallel to the official history of the mission in Goiás. On the understanding of history from autobiographical studies, Lígia Maria Leite Pereira reflects:

The autobiographical writing, Contardo Calligaris reminds us, presupposes a culture in which the individual places himself above the community to which belongs, and conceives his life as an adventure to be invented, and not as a predetermined destiny to be fulfilled. Moreover, if it is true that life stories have always been written, the idea that life is a storyrgiu with the modern era (PEREIRA, 2000, P. II7).

According to Pereira, autobiographical writing makes the individual conceive his life as an adventure to be invented and, the autobiographical narrative begins to be 


\section{G) CitșTórica}

constructed as a true story, the story chained by the narrator himself. This was the story constructed by Corazza, the story of his life as an Orionite priest in the region of the mission object of this study. As noted, in Pattarello's "proposal", he wrote about the need to "drop the stone on the pawn". According to Corazza, the pawn in the case was himself, at the time considered Tonini's trusted man. Pattarello believed that by hitting Corazza, he would also hit Tonini and he would destabilize. That was, then, the strategy: to reach Corazza to "undermine" Tonini's work.

Apparently, that's what happened. From the moment on the missionary Corazza was persecuted by Provincial Pattarello, and even called for a conversation with the Apostolic Nuncio in Brazil at the time, as he recorded in his memoirs: "To complicate the situation, a telegram of Don Alano: Fr. Corazza, the Nuncio Dom Lombardi awaits him" (CORAZZA, 2000, p. 63).

Corazza was summoned by none other than the Apostolic Nuncio in Brazil, the Pope's representative in the country. Certainly, to explain the situation of the Orionite mission in the region. Unfortunately, Corazza did not report in his memoirs the content of the conversation. In his record he himself highlighted the option not to comment. It risks inferring that the conversation could have no other reason than a request for explanation about the intrigues within the Orionite mission in Goiás. Would Pattarello, as provincial of the Orionites in Brazil, implant ed intrigues about the mission, its members and Tonini? It is inferred that it is quite possible that yes. The fact is that significant changes occurred after Corazza's meeting with the Apostolic Nuncio. According to Corazza:

When I got back from Nunciature, the weather was beyond cloudy. It was blurry. I (the pawn), transferred to Sicily. D. Tonini (the little king) tipped over. It was the checkmate. Not for the two of them, who had the grace and strength to keep the faith. The checkmate went to the Orionite Goian mission, hit hard. And how! (CORAZZA, 200o, p. 63).

Corazza recorded that when he returned to Goias after the meeting with the Apostolic Nuncio, he came across reality: he himself was transferred to Italy and, Tonini "tipped", that is, overthrown. As with Foli, it was transferred to Santa Catarina years before. Tonini resigned as apostolic administrator in 1959, moving not only far from Tocantinópolis, but away from Brazil in Uruguay. Corazza called the transfers "checkmate." It is considered to infer that these transfers were the basis of the events that provoked resentments in 


\section{C) CitsistórICA}

Corazza and that decades later led him to consider Pattarello as the persecutor of himself as well as the other missionaries of the Mr. Tonini.

But why were Corazza's resentments taken as an object of reflection in this study? As for the problem of resentments that can be taken as a reflection in historical research, Pierre Ansart considers that the historian, it is also valid to address this theme whose observation is made by other areas of study, such as Psychoanalysis. According to Ansart, for this type of approach, it is necessary to "consider the grudges, the envy, the desires for revenge and the ghosts of death, for they are exactly these [the] feelings and representations designated by the term resentment" (ANSART, 2004, p. 15), and that, it is believed, these factors always occupy space in the life of human beings, regardless of sex, belief and ideologies, elements that in some cases, because they are human phenomena, end up becoming, also, objects of history.

On the transfers, it seems, was Pattarello's victory. He managed to "get rid" of Tonini and it was a complete "victory", since the latter was assigned to another country: Uruguay. Pattarello would no longer deal with Tonini from that moment on. Corazza ended the last record by explaining that Pattarello's "checkmate" was not only in Tonini's group, but in the Orionite mission as a whole, in the work they had done so far. He himself clarifies what had just happened, when dissatisfied, recorded: "Believe who you want. It was all decreed. It wasn't possible that that was true. Everything collapsed, a work carried out with so much love and sacrifice" (CORAZZA, 2000, p. 6I).

As noted, Corazza noted that everything that had happened, i.e. the transfers and Tonini's own resignation had been the result of a project, you can this interpretation due he have written "it was all decreed." But decreed by whom? For Pattarello, the superior dorionites in Brazil. Corazza, dissatisfied, recorded that everything was falling apart, was as if dissthis: destroyed. And ended his registration stating that the work done by Tonini's group of which he was part, would have sgone done with much dedication, love and sacrifice.

It was more than an "outburst" from Corazza, it seems he exposed a huge resentment towards Pattarello. Could it be inferred that Pattarello's interference in the Tonini group of which Corazza was a part and the resulting attacks would have caused such resentment in Corazza? Pattarello, for his attacks and persecutions, caused trauma to Corazza's life? Marc Ferro, in his studies on resentment in history, reflects that in the origin of resentment, whether in the individual or group aspect, there is, most often a wound or even a violence that some individual suffered, which can generate trauma. 


\section{G) AitșTórICA}

Who considers himself a victim and who for some reason had no conditions of reaction, most often feeds resentment, a hurt, a non-conformism. These last elements fuel a desire for revenge and that if not executed, "torments" the alleged victim without truce, until one day explodes. From Ferro, it is inferred that this resentment of Corazza, his nonconformism, "exploded" in the written form, which gave rise to his memory records, object of this study. This "explosion" of resentment can also be accompanied by strategies of disqualification of those who were considered by the victim as "oppressor" (FERRO, 2009, p. $59)$.

Still on the transfer of Corazza to Italy, it is important to note that he considered himself an exile, as recorded:

In Palermo, in Água Santa, headquarters of the mafia, the congregation has a boarding school. There I went to fulfill my exile, as an assistant to the sons of the mobsters. Both in Palermo and messina I had a great pedagogical experience (CORAZZA, 2000, p. 64).

Exile is the condition in which the person is sent or decides to go to another region or country against his will, usually the result of persecution in the country of origin. Corazza felt exiled when he returned to his country - Italy - against his will - because he wished to continue his work in the Orionite mission in Goiás. Feeling exiled, Corazza seemed to be victimized by the fact that he was transferred by Pattarello, since the latter was responsible for the situation. Would Corazza be, considering himself a victim of Pattarello?

On victimization strategies, Tzvetan Todorov reflects that "no one wants to be a victim, there is nothing pleasant about it; on the other hand, everyone wants to have been; They the status of the victim" (TODOROV, I999, p. 225). To if we consider an exile what in fact not was only seen to have been transferred from one country to serve the congregation in another, Corazza, in fact, victimized himself as A Strategy it is believed, to frame yet More Pattarello as sort of "Villain" DThe "suffering" that he felt by virtue of his tranesference of the mission in Goiás. That is, from Todorov, it is inferred that by not conforming to his transfer to Europe, even if he considered himself persecuted by Pattarello, Corazza aproveitou of the situation to consider himself a victim of Pattarello.

Corazza in his records, presented his experiences when transferring to Italy, in fact, the return to his country, since he is Italian. There, he says he's taken advantage of other jobs. Corazza also recorded the fact that he had some of his correspondence intercepted and 


\section{C) HitsớT́RICA}

therefore violated, since they were opened without his consent, by members of the Orionite congregation. On these correspondences he recorded:

Don Carlo Pensa, superior general, visited the Goian mission and did not settle for my transfer to Sicily. I regretted my silence. It happened, however, that my letters were not delivered to him. According to the version of his then secretary, Fr. Zambarbieri, it was not to hasten the death of the superior general, already elderly. That false zeal was refuted by me: The Secretary forgive me. I've always heard that the truth, no matter how hard it is, never kills anyone. On the contrary, it opens the eyes of the living to avoid iniquities, injustices, slander (CORAZZA, 2000, p. 64).

It is interesting to note that Don Carlo Pensa, then superior general of the Orionites in Rome, was the first successor of Don Orione, having been his "right-hand man" for a long time (PATTARELLO, I985, p. 28). In recording that the superior of the Orionites had not conformed to his transfer to Italy, it is believed that Pattarello's movements in the Goian mission were not known to the superior who lived in Rome. Corazza discovered, from this meeting with Pensa, that the letters he wrote to the superior general did not reach his hands, were therefore diverted.

In criticizing Corazza's memory records, one wonders if, in fact, algumas cCorazza's orresponderences were even intercepted by someonereligious of his congregation. Why didn't he in his records bequeathed more information about this episode? When the investigation that gave rise to thisthis concern was a cause for reflection. But still, it is believed, therefore, to be i need to analyze thiss Records of memory about thes Supposed interceptions of his letters as he wrote, as his testimony to the events that he lived, because thessim as Ecléa Bosi:

It is not appropriate here to interpret the ideological contradictions of the subjects who participated in the public scene. What draws my attention is the way in which the subject mixes in his memorialist narrative the personal marking of the facts with the stylization of people and situations (BOSI, I994, pp. 458-459).

It is observed that by recording that some of his correspondences were diverted, he ended up exposing the Orionite congregation as much as possible. Therefore, it should be noted that in Corazza's memory records, he did not separate the "i" from the "medium" in 


\section{G) CitșTórica}

which he lived. His writing, therefore, exposed at all times the Orionite congregation and the practices exercised by some of his superiors. The question of the relationship between the individual and the social groups to which they are linked can be reflected from autobiographical studies. About this relationship, Maria Lígia Pereira reflects:

Personal documents present some distinctions between themselves, such as autobiographies and memoirs. It is a question of intent: did the author want to write the story of his person or that of his time? In the memoirs, the author puts himself as a testimony of his time. If there is no way to abandon the individual point of view, the object of discourse is something that goes far beyond the individual, to be the history of the social and historical groups to which he belongs or belonged (PEREIRA, 2000, p. I24).

Corazza left recorded in his memoirs that he sought to inform the superior general who resided in Rome, about the events that were underway in the Goian mission. To which it should also be inferred that the same correspondencemay have reached the hands of the Superior General. And that, in judging the conflicts that occurred between Pattarello and Tonini in the context of the Goian mission, Don Carlo thinks he has taken a favorable stance towards Pattarello. And later, when he met Corazza, he assumed a position of misunderstanding, or ignorance of what was happening among the Orionites in Goiás.

After three years of transfers, Corazza returned from Italy to Brazil, andthe year 1962. It was closed what he regarded as his "exile" in Europe, far from the mission orionite in Goiás. Upon reaching the Brazil, was sent back to the Goian mission in the city of Araguaina. In the same year, Corazza took charge of seeking mechanisms for the creation of an Orionite schoola city and in the absence of recufor the maintenance of the same, recorded in his memories that he opted For among students and parents, in addition to residents with the best financial condition in the city, resourcesmaintain the school to be set up (CORAZZA, 2000, p. 48).

It is important to note that regardless of Corazza's idea of seeking financial support for the creation of the school, and even the Orionite congregation detains institutions of an exclusively philanthropic nature, a "power orionites, which brought about from that moment on, institutions such as schools, hospitals and even nowadays, colleges. All this institutional action of the Orionites in the region, as it is believed, would not be possible based on philanthropic actions, except when this discourse of philanthropy is used to achieve benefactors in other regions of the world, in the case of orionites, in the Europe then. 


\section{C) HitcastóricA}

The school, at the time, could not charge tuition. A new conflict was again established between Corazza and Pattarello, who in the context was still the provincial of the Orionites in Brazil. Pattarello, according to Corazza, intervened in the plans about the school, as he recorded: "The congregation through its representative, the provincial Father Pattarello, was against that project" (CORAZZA, 200o, p. 7I). Pattarello, by being against the project for the Orionite school in Araguaína, would be again pursuing Corazza? It's believed to be. The fact is, Corazza believed so. Two years after his return to Brazil in 1964, with the support of the mayor of the city, students, parents of students and local donors, Corazza was able to found the school that was named Santa Cruz Gymnasium 9.

Past somens years, Colorazza suffered an accident on BR-I53 near city of Guaraí. In the veícwere three Orionites, Corazza, Father Viana and Brother Macarius. The car, according to him, flipped nthe highway and, of the three vehicle occupants, Corazza was the one who suffered more abrasions. In his memories, he wrote that fhi transferred to the capital, Goiânia, where he received medical help (CORAZZA, 200oP. 75). After the accident, Pattarello claimed that Corazza needed "rest" from the work of school principal in Araguaína and with this "justification" transferredo to the small village of Pineapple, another city of the mission orionite in the region. There Corazza recorded have passed due to difficulties, according to him:

Another month and I got rid of the crutches. The provincial, Father Pattarello, then sent me to replace Father Raffa in Nazareth. I stayed there for six months, with poor food, with nowhere to eat regularly. Except on Sundays, when the mayor's wife, Ms. Ivone, brought me a special lunch. (CORAZZA, 2000, p. 76).

Corazza, in full recovery from the accident, was transferred by Pattarello to a small village, where he certainly could not recover either physically or psychologically from the accident. Resentful of the transfer, he recounted the difficulties he faced. The fact that Pattarello transferred him at a delicate moment in his health, and due to the history of clashes that both had already had, leads to believe that he was, in fact, persecuted. Corazza

\footnotetext{
${ }_{9}^{9}$ This school, currently a college, is the main private educational establishment in the city of Araguaína and one of the main ones in the state. It has a tradition of forming the elite of the city and region. It is an educational establishment practically destined to the most elitist layers of the city, although it offers scholarships to a few students, those with the lowest financial condition. It is worth remembering that the congregation of Orionite priests is recognized worldwide as a congregation based on the charity and humility of its members, the very motto of its founder, Don Orione, was charity.
} 


\section{C) CitsistórICA}

also recorded that not even adequate food had access. As for the interference of the mayor's wife in favor of Corazza, two hypotheses can be established: it was simply a gesture of human charity or, still, a political-religious action of the municipal government, through its first lady, at the time, to " "laurels" from society for helping the Orionite priest.

Still about Corazza's transfer to Pineapple, at a time considered delicate in his health, a fact attributed to Pattarello, reinforces the interpretation that Corazza's memories were moved, in their entirety, by his resentments to Pattarello. At no point does Corazza portray Pattarello, if not by a negative mention. Why did Corazza always record his memories for this bias? How to understand Corazza's successive negative mentions of Pattarello? On this issue, David Konstan infers that resentment "is a complex notion and quite difficult to specify (KONSTAN. 2004, p. 6I).

By analyzing Corazza's memory records, it was concluded that he all the time attributed a negative image to the Pattarel, Newit, i.e. negative image of the Other but never of himself. He autobiograFou as a courageous missionary, fearless, strong, Without problems of any kind. He and Tonini's group of allied missionaries are remembered as unresaved men. Maria Lígia Milk Pereira in his reflections on autobiographies, Notes that's mcommon uito the absence of errors in the life of those who write about themselves. According to her:

Most life stories consist of true apologies. There is a scarcity of wrong or immoral acts, of unfair or violent practices, of fraudulent behavior of almost every kind of part of the writer. Most life stories try to speak with a single voice, without contradictions and without opponents. Almost entire parts of life are left out, especially painful or questionable episodes that could bring damage to the narrator's image (PEREIRA, 2000, p. I24).

According to Pereira, events that may cast doubt on the behavior of the person who narrates about his own life are silenced in most autobiographies. It is inferred that it is quite possible that there have been passages from Corazza's life and not only from him, but also from Tonini, Mecozzi and Foli, which could lead to questioning the image and the very life story of them. It is certain to infer that in Corazza's memory records there was nothing portrayed that would discredit his conduct or the group of missionaries to which he belonged, Tonini's group. But in the memory records of Corazza, the object of this study, and not only of the latter, but of his companions, they presented incorruptible biographies. 


\section{C) CitsistórICA}

Soon after his passage through the village of Pineapple, beset that there was a new transfer of Corazza, this time to Araguatins, another center of the Orionite mission, there lived another period, according to him, still in medical recovery (CORAZZA, 2000, p.79). Years later, in 1971, Corazza returned to Araguaína and returned to the position of director of the Santa Cruz Gymnasium. In the same year, he said, the education department of Goiás offered a partnership with the Orionite school, which would be a "model agreement" for other schools in Goiás. Corazza closed the agreement, but on the condition that until the money was released by the state government, the Orionite school in Araguaína would continue to receive financial support from its students, parents and local donors.

According to him, there was a complaint in the capital, Goiânia, stating that the agreement was irregular and that the Santa Cruz Gymnasium was illegal. According to Corazza, he even had his arrest warrant requested at the time, and soon it was revoked (CORAZZA, 2000, p. 78). Regarding the request for arrest, it is believed that it was a hasty decision of the authorities, either for not knowing the actual facts that occurred, or even, the overvaluation of the complaint, with the aim of tarnishing the image of the missionary.

In their records of memory, Corazza suggested that the ofnuncia was fruit of a frame against him but didn't come to mdirectly endeaare the suspicion About the participation of Pattarello in this last case. Anyway, whether you are the complainant or not, Pattarello, according Corazza, he took advantage of the Situation:

Father Pattarello, the Provincial, did not miss the opportunity. He applauded the confusion and convened a meeting of the entire faculty of the school, without my knowledge, also inviting the Superior General of the Congregation, Don Zambarbieri, who had come from Italy and was passing through Araguaína at the time. The final decision was an irreversible order: Remígio had to leave. And so it happened. When I was at the junction to board, Leonino Caiado, then governor of Goiás, passed occasionally and, seeing me there, stopped the car and said: "Father Remígio, your bosses are worse than Colonels, I could not do anything". Thank you, Governor. Don't be scandalized. In religion politics is like that sometimes. When it's not worse. To reassure my spirits, I traveled to Bethlehem as a guest of a fellow friend, Father Hélio Frizon (CORAZZA, 200o, p. 79).

As exposed by Corazza, Pattarello "took advantage" of the complaint involving the alleged irregularity of the agreement between the Orionite school and the education 


\section{C) CitsistórICA}

department of Goiás, and again came into conflict with Corazza. This last record of Corazza reinforces the interpretation that Pattarello did nothing to avoid clashing with Corazza, which reinforces the interpretation that the latter was, to a greater or lesser extent, pursued by Pattarello. Is Pattarello's attitude - of not avoiding conflicting with Corazza - the biggest cause of so much resentment in the latter? It's believed to be.

Apparently, Pattarello didn't even have any affection for Corazza, and worse, he didn't miss an opportunity if he wanted to, to face him. It was Pattarello's attitude responsible for the origin of Corazza's resentments? Pierre Ansart, when reflecting on memory and its relationship with resentments, infers that "one can hardly accept the hypothesis that a feeling, from which we emphasize intensity and strength, has no consequences or manifestations in the conducts of individuals" (ANSART, 2004, p. 2I).

After the complaint, according to Corazza, A GatherWill was convened by Pattarello to decide the your Futuro as then director of the school. The meeting had the participation of the superior general of the Orionites, that is right, the number one Orionite of the congregation in the world, andpassing through Araguaína at the time. It is considered that mais surprisesthat participation in the from the upper of orionites at the meeting, was the fact that the complaint occurred justamduring the visit of the even to the city of Araguaína. Cthe incidence, by the way, very Unhappy for Corazza.

At the meeting it was decided for his removal. By the way, for the second time Pattarello managed to drive Corazza away from the direction of the Orionite school in Araguaína. Even more emblematic was the entry into "scene" of the then governor of Goiás, Leonino Caiado, who according to Corazza, was also passing through Araguaína at the time. Corazza in his narrative recorded that the governor had told him that he had not been able to help him and that the Orionites, Corazza's superiors, were "worse than colonels" (CORAZZA, 200o, p. 8I).

It is observed in the dialogue between Corazza and Caiado, which can be, on the part of the two, the exposition of the Orionite congregation in the worst possible way, as an environment "contaminated" by disputes and intrigues. In this way, Corazza was again hit by Pattarello. He recorded Pattarello's plans at the meeting: the decision of the superior of the congregation was to remove him from the school board again. In his memory records, Corazza presented his truth about the facts he lived through. On the mechanisms of constructing the truth of himself in autobiographical writings, reflects Michel Foucault: 


\section{C) CitsistórICA}

Writing as a personal exercise by you and for you is an art of disparate truth; or, more precisely, a rational way of combining the traditional alterity of the thing already said with the singularity of the truth that is affirmed in it and the particularity of the circumstances that determine its use (FOUCAULT, I983, p. I5I).

According to Foucault, the writing of himself ends up being what he calls the "art of truth". The truth that is constructed and constituted by the narrator of his life, in this case, the Orionite missionary Corazza. Still on this mechanism of construction of truth by the narrator, Foucault adds that the truth constructed by the narrator will be at the service of the circumstances that will guide the use of it. In this case, the truth that was elaborated by Corazza was and is still circumstantial to the use he intended to give her: to show that he was persecuted by Pattarello and how he was persecuted by him.

But Corazza, an Orionite missionary who is a strong, fearless and courageous personality, ended up meeting Pattarello years later. The meeting was in 197I. This was, according to his memory record, the last meeting between the two, which took place in Goiânia. About the moment he recorded:

When the storm subsided, two months were passed. They called Father Hélio, setting up a meeting with me in Goiânia. It was a cloudy morning. There was a gentle breeze in the air. The meeting took place behind the Church of St. Paul the Apostle. Take a look at this memo first. After reading the eight items the provincial priest stammered: How do you still remember all this? They're wounds you opened. There was no healing, no lenitive. They're still open, bleeding. Weeping, the Provincial asked me to stay in Goiânia. What's the point? Asked. Father Tonelli was tired and old, needed medical attention in São Paulo. Before he left, he wanted me to replace him in the parish. In view of this I took over the Parish of St. Paul the Apostle in Goiânia. Before taking office as vicar in Goiânia I went to visit my relatives in Italy (CORAZZA, 2000, pp. 79-80).

Corazza was called by Pattarello for the conversation. Corazza's gesture is surprising: he reported that he delivered a "memo" to Pattarello, certainly a paper punctuating everything Pattarello had ever done badly towards him Corazza and the missionaries in Tonini's group. He recorded that there were eight items outlined there. $\mathrm{He}$ 


\section{C) HististóricA}

noted that Pattarello was impressed that Corazza remembered all the events that shocked the two. Corazza replied that they were "wounds" opened by Pattarello and worse, that at that time of the meeting, in I97I, still "bled".

Corazza expressed all his resentment towards Pattarello, for everything he had done against him and against the early missionaries, including Tonini, Mecozzi, and Foli. Apparently, the meeting was a "reckoning" between the two. Corazza, seen as fearless, the man of the "front line" and, in front of him at that moment, in Goiânia, was none other than Pattarello, his "tormentor". Why, so long after the events of the I950s, did Corazza, in writing his memory records, not seem to have overcome his sorrows and resentments towards Pattarello?

On Corazza's difficulty in overcoming his resentments for Pattarello, David Konstan reflects that: "even in his popular sense, resentment seems to suggest a persistent state or feeling, rather than a reaction to a particular and immediate stimulus" (KONSTAN, 2004, p. 62). In fact, from Konstan, it is inferred that Corazza's resentments for Pattarello did not fade over a time distance of two decades, they persisted.

Corazza Registered that Pattarello wept before him. Can this crying be interpreted as repentance? Yes, you can. But it can also be interpreted as no repentance, since he did not apologize, or rather, he didn't ask Corazza's forgiveness. From Pattarello at that instant, Corazza just regcried. NWill whether it can assign a clearer meaning for the gesture of crying of Pattarello, except Infer that it's possible you regretted itof the. But it is still possible Say That Pattarello powould have taken a "step" ahead and harnessed the moment to recognize that there was Wrong acted badly or, in religious language since they were religious, committed many, many sins. But he didn't.

Corazza's memory record of the last meeting between the two went down in history with Pattarello's weeping gesture and his consequent silence. There was therefore no request for Pattarello's forgiveness from Corazza. Much less Corazza stepped forward to forgive him. Quite the contrary, from Corazza's narrative, at the time he delivered a document he called a "memo" to Pattarello, it is believed, a list of his "evils". It is also possible that Pattarello's cry did not even exist. Or if it existed, it wasn't true, we won't know that.

By noting that there was no request for Pattarello's pardon and, consequently, repentance, would this not be Corazza's strategy of absolving himself in the conflict with Pattarello? We won't know anyway, it's just possibilities. Regarding these questions and the impossibility of elucidating them much more accurately, it is agreed with Pierre Ansart that 


\section{C) CitsTTórICA}

"it is certainly much more difficult to trace the history of hatreds than the history of objective facts" (ANSART, 2004, p. 2I).

From Corazza's memory record, there was no public demonstration of Pattarello's forgiveness to Corazza at the last meeting between the two. So, if in fact there was no request for forgiveness, how to understand Pattarello's attitude towards Corazza? How can Corazza not get ahead of himself and, seeing Pattarello cry before him, offer him forgiveness? Paul Ricoeur, in his studies on forgiveness, in the historical condition, does not rule out the possibility of reconciliation with the past through the eschatological perspective of forgiveness, but warns:

Forgiveness, if it has any meaning and if it exists, constitutes the common horizon of memory, history and forgetfulness. Always in the background, the horizon escapes the domain. He makes forgiveness difficult: neither easy nor impossible. It prints the seal of the infinish on the entire endeacity. He's as hard to give and to receive as he is to conceptualize himself. The trajectory of the forgiveness has its origin in the disproportion that exists between the two Poles lack and forgiveness (RICOE, New YearUR 2007, P. 465).

Ricoeur questions whether forgiveness actually exists and whether there would be any sense in it. He says forgiveness is hard. If the key to forgiveness would be in the "shutdown" of the subject with his action, it is worth really agreeing with Ricouer that forgiveness is difficult. So much so that Pattarello did not ask Corazza's forgiveness, he was limited, according to the latter, to crying at the last meeting between the two. No one more than Pattarello knew and should be aware of everything he had ever done against the missionaries. So difficult though that Corazza didn't help himself to offer him forgiveness. Why did Paul Ricoeur theorize that forgiveness in history is difficult? He reflects on this difficulty by inferring:

If justice is even to be done, otherwise the impunity of the guilty is enshrined, forgiveness can only take refuge in gestures incapable of becoming institutions. These gestures that would constitute the incognito of forgiveness designate the inescapable place of consideration due to every man, singularly to the guilty (RICOEUR, 2007, p. 466). 


\section{C) CitsistórICA}

From the reflection of Ricoeur, it is clear why forgiveness is difficult. He says that the belief in justice and the need for this to prevail makes forgiveness become an "incapable gesture." Thus, Pattarello's refusal to ask Corazza for forgiveness by merely crying before the latter, and the consequent fact that Corazza did not advance in offering Pattarello forgiveness would, then, on the part of both, represent this desire for justice, after all, to be done? And so, justice done, the gesture of forgiveness would be incapable of putting an end to that pending between the two? From Ricouer's reflection, it is believed that it does.

Anyway, from Corazza's memory record, there was no forgiveness between the two Orionites. For Ricoeur, forgiveness, if it exists, "breaks" the debt, but would not make it forget, because for him it is a relative oblivion of the debt, not the fact itself. So, according to Ricouer, forgiveness is not a requirement, but a request that can face refusal, the unforgivable, hence forgiveness for it to be possible, but difficult. In fact, it was so difficult for the two Orionites that he didn't exist on the last date.

\section{Final considerations}

The purpose of this study was to unveil the conflicts that occurred within the Orionite mission, from the perspective of one of its missionaries: Corazza. From what he revealed clearly or between the lines showed, it is inferred that yes, there were persecutions and conflicts between the Orionite missionaries at the time, especially those who were appointed by Corazza as a kind of "villain" of the process: Pattarello. Why did Corazza appoint Pattarello as a stalker? Becausehe narrated what he lived within the mission, because, like Walter Benjamin, it is believed that "The narrator tells what he extracts from his experience - his own or that told by others. And back, he makes it an experience of those who hear his story" (BENJAMIN, 1985, p. 197-22I).

The objective that was proposed from the beginning was to observe the mission from Corazza's perspective and exclusively through it. Why did you focus on approaching the behind-the-scenes mission from Corazza's perspective? Because Corazza's memories can only be associated with the Orionite mission and its members, because, like Ecléa Bosi, it is believed that "the memory of the individual depends on his relationship with the family, with the class, with the school, with the church, with the profession; finally, with the groups of conviviality and with the reference groups peculiar to this individual" (BOSI, I994, p. I7).

But some problems can be pointed out by criticizing the use of Corazza's memory narratives as a single source for establishing generalizations such as believing that 


\section{C) HististóricA}

persecutions and conflicts have actually occurred between some Orionites. But at the same time, Corazza's memory narratives may not have been the real mirror of the events that occurred at the time. But their choice, from the methodological point of view, was due to the fact that Corazza was the only one who sought to show the Orionite mission by what from his point of view, in addition to other things, it was: environment of dispute and persecution implanted by one of his most imminent members: Pattarello.

It is not, therefore, a question of having given voice to an Orionite who only "complained" of another Orionite. But someone who in his own way explained in detail what he watched and lived. Corazza's truth, therefore, may not be the universal truth of all the missionaries involved in the mission at the time, but it is the truth of it, and it is precisely the truth of Corazza, the object of this study. Corazza's truth, imbued with resentment, was constructed logically, the logic he found to trigger his narrative, his memory records. It is still important to infer that these Corazza memory records, their truths, may contain absences of minute details such as precise dates and etc. These absences did not compromise the reflexive capacity of this study, as it is believed, in line with Ecléa Bosi, that:

Sometimes there are slips in the temporal location of an event. Chronology failures also take place with extraordinary events of childhood and youth. Some and the other undergo a process of disfigurement, because group memory is made up of individual memories (BOSI, 1994, p. 4I9).

Through the attentive analysis of Corazza's written memoirs as well as dialogues with subjects who did not participate in the events of the I950s, but who heard reports from them, these narratives corroborate the interpretation that, to a greater or lesser extent, behind the scenes of the Orionite mission ended up causing significant changes in its progress. As discussed earlier, the two biggest changes were: Tonini's resignation and, second, the transfers to which the missionaries who orbited his return were submitted, among them, Corazza himself.

What is the relevance, therefore, of religious conflicts for the missionary activity of the Orionites in the region? This relevance is precisely the hypothesis previously raised because, as it was possible to perceive, from Corazza's reports and a record of Foli, it was seen that the missionaries who were under the influence of Tonini, including Corazza himself, were transferred from mission on Goiás soil, to other regions of the country such as Foli, others like Tonini and Corazza, sent out of the country. The only one who was not transferred was Mecozzi, then appointed as vicar capitulant of the prelature, a position he 


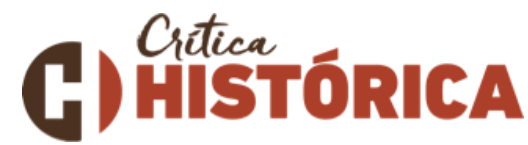

held for a year. Certainly, the transfers of the main missionaries resulted in a change in the course of the mission at the time in Goiás. The departure of these missionaries caused new Orionites to be moved to Goiás. Tonini's own departure, at the time considered the main one among them, paved the way for the appointment of the first bishop to the region: Cornelius Chizzini.

It was seen, still in this study, that the first decade of the Orionite mission in the region revealed the importance of a missionary: Mr. Tonini. As we know, he became apostolic administrator in the region subject of this study and was listed, thewhat it looks like to be named bispo of Tocantinópolis. Tonini did not count at the time with Pattarello's joints that, according to Corazza, he did everything to dismantle both his work as apostolic administrator, and o group of missionaries who were in their zone of influence. The proprio Corazza, along with Foli, New Year, were transferred from the mission, Tonini, as we know, resigned in 1959 to the direction of the same, resignation about which until his last day of life did not want to reveal in writing.

On Tonini's resignation, several hypotheses can be established. First, knowing that the Orionite mission in the region was experiencing difficult days, the result, for example, of the disputes between his group and Pattarello, he sought to cease, with his resignation, the situation then faced, in the name of peace among the religious and zeal for the church in the region. The second hypothesis, perhaps, the awareness that he did not have enough strength to fight the attacks of Pattarello, at the time, provincial of the Orionites in the country. There may still be a third hypothesis, that Tonini may have resigned as a strategy to protect the figure of Foli, because, as previously written, it seems, both fed a passion until the last days of their lives.

On this last hypothesis, would Tonini have resigned from office, under pressure from Pattarello, to protect everyone from the revelation of a "scandal" within the Orionite mission at the time? The scandal of your supposed passion for the then nun, Foli? Is this even the reason for Tonini's silence on the case until the final days of his life? But why then did he have to resign rather than be replaced? As previously written, Tonini emerged from prestige in the Church at the time, and was even considered the main missionary in the region. Its replacement would generate instability in the mission or, it would require a plausible justification on the part of his superiors, in this case, in Brazil, his superior was none other than Pattarello. It is inferred that it was from the latter that came the pressure for Tonini's resignation, rather than a simple replacement. 


\section{G) Hiticátórica}

On the resignation of Tonini and the removals of Corazza and the other missionaries, what is the official version of the congregation for these events? Absolutely no version has ever been given, either privately or publicly. The congregation since the initial years of the mission in Goiás has always had mechanisms for disseminating its actions as a magazine. They could have perfectly used these official publications to explain the events involving their chief missionaries, but they did not. A surprising silence prevails to this day when it refers to the events involving the missionaries mentioned in this study. This silence, it is believed, reinforces the conviction that these events involving the Orionites at the beginning of the mission in Goiás - conflicts, persecutions, disagreements - represent moments about which the Orionite congregation in Brazil intended and also want to forget, put them as a "page turned". For this reason, Corazza's versions for these events become a unique source for the events objects of this study.

But Corazza may have been the Missionary who suffered the most Pattarello's persecutions. According to his memories, fhi transferred several times from place as also stripped of his duties of director dand Orionite schools. Records of his memory reveal the maneuvers practiced by Pattarello so that from these reports, it was possible to Imagine the events with narrative details worthy of a plot of cinema.

Despite the fact that Corazza was the missionary who was most persecuted by Pattarello's attacks, Corazza does not seem to have faced him, fought back, with the exception of the correspondence sent to the superior of the Orionites in Rome and which, according to him, were deviated, Corazza did not publicly denounce Pattarello at the time. As we know, he left to report the persecutions to which he was subjected in his autobiographical book, his memoirs, reserving the role of victim in this story. Corazza, in fact, chose to victimize himself, this was his strategy in relation to Pattarello.

As seen earlier, they met years later and at the meeting Pattarello would have wept as he was reminded - including with a written document - about his wickedness. It is impossible, at first, to know whether Pattarello's cry was one of repentance or not. Corazza, extremely resentful of Pattarello, did not help but forgive him. From the reflections of Paul Ricouer, the last meeting between Corazza and Pattarello was understood: from the meeting emerged a certainty already outlined by Ricouer: forgiveness in history is really difficult.

As it is also difficult to historicize certain historical processes when there is a shortage of certain types of sources, in this case, sources that explore the Orionite mission and the behavior of its members from an internal angle: that of the backstage of the mission, objective of this study. For this reason, this was the greatest difficulty encountered for the 


\section{C) CitsistórICA}

construction of this study. That is, the only written source about the Orionite missionaries that reveals the deeds of these religious in the private perspective is Corazza's memory record.

Hence the fact that Corazza's memory register, his autobiographical book, was used as the exclusive source of this study. By choosing this path, Corazza's memories were transformed into a document, a necessary procedure as Michel de Certeau warned, when, in the historiographic operation, he defended the need to "separate, gather, transform into documents certain objects distributed in another way"(CERTEAU, I982, p. 8I). "Certain objects distributed in another way" was what we sought to undertake in this study, to give chaining and meaning to these narratives by Corazza, transforming them into documents for historical analysis.

Evidently, Corazza's memory records are not the only possible sources about the Orionites. But it is insisted that the behind the scenes of the mission are, without a doubt, the only source. Other records and sources about the Orionites exist, but from the perspective that was privileged in this study, no. It is important to highlight that during the making of this, with the exception of Corazza, all the other missionaries mentioned were no longer alive, which made any possibility of collecting oral testimony unfeasible. In addition to this difficulty, Corazza himself, already almost a hundred years old, takes refuge in the main Orionine church in Araguaína, in a wheelchair, sick and incommunicable.

Finally, it is known, therefore, from Corazza's memory reports and from the perspective of the latter, the backstage of the Orionine mission at the time. But what representation did the other characters involved in this story have about these same events, but who were not the subject of this study? As noted, other approaches can help to understand the Orionine mission in the region. This study, based on Corazza's reports, is just one among other readings still possible about these characters and their deeds.

\section{References}

ANSART, Pierre (2004). History and memory of resentments. In: BRESCIANI, Stella \& NAXARA, Marcia. Memory and Resentment: Questions on a sensitive issue. Campinas: Unicamp Publishing House, 2004.

AZZI, Riolando ( The Neocristandade: A Restorative Project. History of Catholic Thought collection in Brazil - V. São Paulo, Editora Paulus, 1994.

BENJAMIN, Walter (2004). The narrator: considerations about the work of NikolaiLeskov.In: . Magic and technique, art and politics: essays on literature and history of culture. Two, second. São Paulo: Brasiliense, 1985. P. 197-22I. 


\section{C) Hitceatórica}

BOSI, Ecléa. The living time of memory: essays of social psychology. São Paulo: Atelier, 2003. . Memory and Society: Lembranças de Velhos. $3^{\mathrm{a}}$ ed. São Paulo, Companhia das

Letras, 1994 .

BOX, Vera Lucia. Doctors, Friars and Intellectuals: Readings on the Sertões of Central Brazil (I882-I935). Curitiba, CRV Publishing House, 20I4, p.89.

CERTEAU, Michel de. The writing of history. Rio de Janeiro, University Forensics, 1982.

CORAZZA, Remígio. Prudent Silence. Fortaleza: Expression, 2000.

IRON, Marc." The Resentment in History. Rehearsal. Agir Editora: Rio de Janeiro, 2009.

FOLI, Teresinha de Jesus Nóbrega. Insands of Truth. Fortaleza: GM, 2003.

FOUCAULT, Michel (2004). The Writing of You. IN: Ethics, Sexuality and Politics. Rio de Janeiro: University Forensics, 1983.

GAY, Peter. The Common Trait, In: The Unveiled Heart: the bourgeois experience of Queen Victoria toFreud. São Paulo: Cia das Letras, 1999, pp.337-376.

KONSTAN, David (2008). Resentment - History of an Emotion. In: BRESCIANI, Stella \& NAXARA, Marcia. Memory and Resentment: Questions on a sensitive issue. Campinas: Unicamp Publishing House, 2004, p. 59-8I.

PATTARELLO, Giovanni (2009). Dom Orione's Profile. São Paulo: S/Editora, 1985.

PEREIRA, Lígia Maria Leite ( Some Reflections on Life Stories, Biographies and Autobiographies. Oral History. Mariana: FAFICH/UFMG, 2000.

RICOEUR, Paul (2009). Memory, History, Forgetfulness. Campinas: Unicamp Publishing House, 2007.

RODRIGUES, Jean Carlos (2004). Space and Religion: The Presence of the Congregation of the Small Work of Divine Providence in the Ancient North of Goiás (I950-1970). Revista Escritos, Vol.8, N.I, pp.42-54, 2016.

SILVA, Raylinn Barros da. Orionite Catholicism in the Old Northern End of Goiás in the Accounts of Memory of the "Sons of Divine Providence" 1952-I980. Master's thesis. Graduate Program in History. Goiânia: UFG, 2017.

. Love and passion behind the scenes of a Catholic religious mission in the hinterland of the extreme north of Goiás (present-day northern Tocantinense): Quinto Tonini and Teresinha Foli in their memory accounts. Albuquerque: History Magazine. Vol.Io, Number 19. January to July 2018, p.195-220.

TODOROV, Tzvetan (2009). The man uprooted. Rio de Janeiro: Record, 1999. 
(G) Hiticátórica

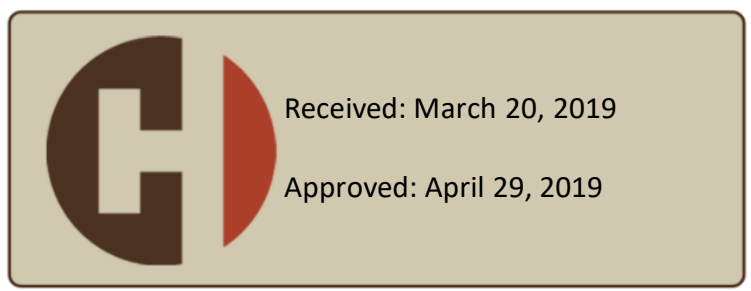

